\title{
Persuasion, slack, and traps: how can economists change the world?
}

\author{
Bryan Caplan
}

Received: 1 September 2009 / Accepted: 1 October 2009 / Published online: 20 October 2009

(C) Springer Science+Business Media, LLC 2009

\begin{abstract}
Contrary to my critics, voter irrationality does not imply that economists cannot mitigate political failure. With rational voters, reform-minded economists have few viable tactics; with irrational voters reformers have more options. Rational voters can be swayed only by facts and logic; irrational voters could respond to better rhetoric. Rational voters strategically punish those who ignore their policy preferences; irrational voters use less effective disciplinary strategies that create political slack. Even with irrational voters, efficiency-enhancing reform is hard. With rational voters, however, democracy's failure to adopt a reform is strong evidence that the reform does not enhance efficiency.
\end{abstract}

Keywords Voter irrationality $\cdot$ Political failure $\cdot$ Economic reform

\section{Introduction: fatalism and The Myth of the Rational Voter}

In The Myth of the Rational Voter (Caplan 2007; henceforth MRV), I argue that economically inefficient policies survive by popular demand. The public systematically misunderstands economics - and probably many other policy-relevant subjects-leading voters to support policies contrary to their best interests. I also maintain that the public's misconceptions are, in a sense, willful. Most people embrace political and economic beliefs on the basis of their emotional appeal, not dispassionate analysis.

The rest of this paper takes these claims for granted, and pursues their implications for beneficial social change. Many readers interpret $M R V$ as a defense of fatalism-the view that political failures, however disastrous, are an inevitable byproduct of human nature. If the typical voter is as irrational as I claim, aren't we basically stuck with the status quo?

I thank Elle Cohen and Marta Podemska for excellent research assistance, the Mercatus Center for financial support, and members of the Ratio Institute and the Mont Pelerin Society for helpful comments.

B. Caplan $(\varangle)$

Department of Economics, Center for Study of Public Choice, and Mercatus Center, George Mason University, Fairfax, VA 22030, USA

e-mail: bcaplan@gmu.edu 
What can economists do, other than talk amongst themselves and shrug their shoulders in the face of human folly?

The thesis of this paper is that this fatalist interpretation is not correct. While $M R V$ does suggest that radical policy change is difficult to accomplish, every sensible theory of politics says the same. After all, if radical change were easy, it would happen all the time. Nevertheless, difficult does not mean impossible. The text of $M R V$ specifically highlights channels through which idealistic economists can improve upon the status quo. This paper elaborates upon these channels-showing that my book is far from a fatalist tract.

\section{Irrationality and persuasion}

Part of the appeal of rational voter models is their message of hope: If an economist-or other social critic-figures out a way to improve upon existing policies, political entrepreneurs will eagerly take the new idea to the electorate. If the new idea is in fact a good one, the political entrepreneurs will be able to persuade the electorate of its value. The electorate will in turn reward the far-seeing statesmen for bringing a new and improved version of the status quo. The thesis of voter irrationality seems to pull the plug on this presumption of progress. If voters are irrational, what hope is there of persuading them?

On closer examination, though, the standard rational voter story is far less hopeful than it sounds. Yes, if rational voters give politicians strong incentives to champion good ideas, then an economist who develops a good idea can expect to see it implemented. But basic logic allows us to reverse this reasoning: One can with equal validity argue that any idea that fails to be implemented is actually bad (Wittman 1995). Consider, for example, the standard economic arguments for legalizing the market for human organ donation. Rational voter models tell us that if this is a good idea, it will be adopted. They also imply, however, that the failure of this policy to be adopted shows that the standard economic arguments are wrong or incomplete. While critics of the economics profession might be happy to hear this, any economist who thinks that the discipline is full of unheeded wisdom should be dismayed.

At least in democracies, then, voter irrationality is actually a necessary condition for the possibility of major policy improvements. Economists who think their discipline points the way to beneficial social change must begin by losing some of their faith in the average voter.

Why then do some critics take away a fatalist message from $M R V$ ? Their complaint, I suspect, is that voter irrationality takes away with one hand what it gives with the other. Yes, voter irrationality opens up the possibility that very different policies would be superior to the status quo. At the same time, though, it removes the possibility that these superior policies will actually be adopted. If voters are so irrational, how can anyone persuade them?

The tacit assumption behind this argument is that irrational voters are ipso facto dogmatic, unwilling to change their minds in the face of argument. This assumption is deeply mistaken. Yes, irrationality can lead to stubborn adherence to one's current beliefs. But this is only one of many possibilities. Rational voters reliably adjust their beliefs in the face of facts and logic. Irrational voters, on the other hand, might adjust their beliefs in response to anything. Facts and logic might work, but then again so might our presentation-the way that we frame the argument, the values that we appeal to, or our choice of words. ${ }^{1}$

\footnotetext{
${ }^{1}$ Some of my critics, especially my colleague Levy (2008), will correctly infer that lies and fallacies might work too, and point to this as further evidence that I am promoting a "noble lie" strategy for social change.
} 
If I am right about voter irrationality, then, economists who want to change the world should start thinking harder about presentation - the best way to communicate the insights of economics in a compelling way. I don't claim to have figured out economists' optimal persuasion strategy. I hope that my research inspires economists to do serious research on this topic, presumably building on established insights from psychology. I do claim, however, that most economists' persuasive strategies are so bad that we can easily improve upon them.

When economists address broader audiences, the same negative reviews keep coming back. The most common complaint, no doubt, is simply that economists are boring. Our delivery is dry and stiff; we act like we are reading a paper aloud instead of actually talking to people. (Indeed, sometimes we are reading a paper aloud!) A second complaint is that economists refuse to give a clear conclusion. Harry Truman famously wished for a "onehanded economist" who could not respond to every question with "on the one hand... on the other hand." The problem, in essence, is that economists hate to simplify-even when the alternative is communicating nothing at all.

In MRV (Caplan 2007, p. 202), I offer three rules of thumb for economists to escape from these lamentable rhetorical habits:

1. Highlight the contrast between the popular view and basic economics in stark terms.

2. Explain why the latter is true and the former is false.

3. Make it fun.

The first rule is crucial for economists who actually want to nudge public opinion in a better direction. Glossing over the contrast between the popular view and the right view may be a good way to make friends, but it does not advance the cause of truth. Defending the right view without highlighting its conflict with the popular view is scarcely better. People will naturally assume that the two are somehow compatible, and therefore continue to believe what they have always believed. If an economist aspires to change the world, he needs to make it absolutely clear that experts think the majority is wrong. This will alienate many listeners; but if you want to uproot popular economic misconceptions, there's no avoiding it.

Of course, explaining that economists disagree with the public is unhelpful if you are too coy to take sides. This is the motivation behind my second rule. Economists who want to change the world need to take straightforward positions, and succinctly explain their reasons. The less time the economist has the floor, the more important it is to get to the point.

Contrary to some of my critics, this does not mean that economists should embrace "the noble lie." There is a crucial distinction between simplifying and lying-between approximating truth and embracing error. Suppose a farmer tells you that the highway is "five miles ahead." If you later learn that the true distance was 4.96 miles, would you call the farmer a "liar"? I think not. Instead, you would accept "five miles" as a roughly correct simplification-even if the farmer failed to explicitly state that his directions were rounded to the nearest mile. In the same way, economists should not be embarrassed to publicly state that "free trade is the best trade policy." Yes, there are rare technical conditions under which free trade is suboptimal; but "free trade is the best policy" is a good description of the truth-a simplification, not a lie.

My third maxim for effective economic persuasion is "Make it fun." For a fully rational audience, it doesn't hurt to be boring; facts and logic are all that count. When an economist

I insist, however, that there is a difference between noting that a rhetorical strategy might work, and actually advocating it. If you value honesty, as I do, you can admit the persuasiveness of deceptive rhetoric without engaging in it. 
speaks to an audience of actual human beings, though, entertainment is a vital pedagogical lubricant. If we put our own undergraduates to sleep, how are we supposed to sway a broader audience? To repeat, this does not mean that economists should engage in deception; I merely advising economists to wrap their high-quality products in more attractive packaging.

There is more than one way to make economics fun, and I hope that future research will compare and contrast the effectiveness of different approaches. Personally, however, I embrace blunt delivery of economic principles, shocking examples, and ridicule of popular economic illiteracy. I often explain to my students, for example, that almost all of them have one kidney to spare, and that their donation would let another human being escape from the purgatory of dialysis. Legally, however, the law freezes the price of kidneys at zero, leaving no incentive to donate. Defenders of the status quo are causing untold misery, and for what?

One of the main reasons for irrational economic beliefs, in my view, is that they are part of most people's sense of identity. They believe in protectionism, immigration restrictions, and price controls because these are the kinds of things that "People like us think." Another part of my persuasive strategy is to gradually change my audience's sense of identity. On the one hand, I explain, there is the vast majority mired in economic misconceptions. On the other hand, I point out, there is an articulate minority of economists who have spent centuries combating popular prejudice. The subtext of almost every lecture I give is, "Which of these two groups do you want to be a part of?"

One could fairly object, "These same techniques could just as easily be used to spread error." My response is simply that almost everyone other than economists is already using them. Economists have, in effect, unilaterally disarmed-and their influence deficit is no surprise. I understand when economists object that "We do not want to sink to their level." But the key problem with non-economists" "level," is not their effective use of rhetoric; it is the fact that they don't know what they're talking about.

\section{Irrationality and slack}

In a world of rational voters, it would be extremely difficult for economists to shape policy (Caplan 2009). Even if they were high-ranking government officials, they would have very little "slack" or "wiggle room." Their decisions would be tightly constrained by public opinion.

To see why, consider a simple political principal-agent model. The politician is the agent; the voters are the principals. Suppose a politician wants to funnel money to unpopular special interests. In a world of perfect information, of course, the politician will not succeed; the voters will find out and punish him at the polls. Even in a world of costly monitoring, though, voters have a simple way to handle politicians' bad behavior: Punish them with a "probability multiplier" to ensure that defying the will of the people doesn't pay (Becker 1968). Voters might throw a politician out of office for a minor offense, or jail him for petty corruption. Faced with these incentives, political shirking does not pay.

At first glance, this might not seem relevant for appointed officials or career civil servants. With rational voters, however, it is quite relevant indeed. When unelected subordinates act contrary to the public's preferences, the rational response is to punish their elected superiors (Caplan 2007, pp. 172-176). This gives politicians strong incentives to (a) choose their appointees wisely, and (b) give their subordinates incentives to "Do what I would have done if I were fully informed." In other words, if a politician responded to a scandal by saying, 
"Don't blame me for this, it was my subordinate's fault," rational voters would bluntly respond, "Either you're lying, a bad judge of character, or too incompetent to control your employees. All three stories are good reasons to punish you."

To solve the political principal-agent problem, then, voters merely need to (a) impose probability multipliers to compensate for imperfect information, and (b) hold elected officials responsible for the actions of their unelected subordinates. Given these incentives, neither politicians nor their employees would have much room to deviate from public opinion. Accepting a political appointment or running for office in order to "make a difference" would be futile.

To escape these admittedly implausible and contrived implications, we once again merely need to discard the rational voter assumption. The fact that rational voters could easily solve the political principal-agent problem does not show that real voters do so. If voters fail to compensate for imperfect information with probability multipliers, politicians can profitably defy them. And if voters fail to hold elected officials responsible for the actions of their unelected employees, politicians may allow-or even encourage-members of their team to push for unpopular policies. Voter irrationality gives policy-makers "slack" or "wiggle room" to deliver policies that public opposes.

The surprising upshot: It is voter rationality, not voter irrationality, that supports fatalism. With rational voters, policy-makers have to do whatever the public wants; they can't "make a difference." With irrational voters, in contrast, policy-makers may be able to give the public the policies that it needs, rather than the policies that it wants.

Consider, for example, the gradual reduction in trade barriers over the last few decades. The median voter opposes these policies. ${ }^{2}$ If he were rational enough to apply the principalagent strategies outlined above, none of the major trade agreements would have passed. Politicians who supported liberalization or allowed their subordinates to do so would be harshly punished. In the real world, however, the political cost of supporting free trade is milder. Some politicians support it openly; others complain about free trade but do little or nothing about it. When politicians hire economist advisors who support free trade and other unpopular positions, the public almost never retaliates at the polls. It is no wonder, then, that free trade has made so much progress: Policy-makers can support it despite its unpopularity, and the irrational electorate lets them get away with it.

If an economist wants to change the world for the better, then, my next piece of advice is: Find out how much slack you have to push policy in a better direction, and take full advantage of it. If you are an economist involved with international trade policy, do your best to nudge things in a free trade direction. If you are the head of the CEA, use your influence to foil or dilute populist policies. If you are one of the rare economists who holds elected office, slack lets you do good (or at least mitigate harm) while doing well.

How much slack do economists really have? To the best of my knowledge, we still know little about this topic, making it a fruitful one for future research. But there is one case I know from first-hand experience. As a tenured professor at a state university, I have a massive amount of slack. I doubt that the voters of Virginia want me to criticize their economic illiteracy in my teaching and research. But I criticize them nonetheless, and the voters let me get away with it.

Can't slack be used to make policy worse instead of better? Of course. Slack, like persuasion, creates opportunities for anyone to nudge policy in his preferred direction. Yet this is no reason to economists to unilaterally disarm. Other policy-makers use slack to make policy worse; why should economists be ashamed to use slack to make policy better?

${ }^{2}$ See Caplan (2007, p. 218) for detailed citations. 
It is worth adding, moreover, that most economists' comparative advantage is probably in using political slack, not directly persuading the public. Most economists simply aren't trained to win over a broader audience. When they enter the public forum, they go headto-head with practiced demagogues. To successfully compete here, economists need new skills. In contrast, economists are already well-positioned to use slack to push policy in a better direction. Governments around the world employ economists and rely upon them for advice. These economists are already plausibly responsible for the spread of free trade. Who knows how much more we could accomplish if we put our minds to it?

\section{Finding the right trap}

It is hard to deny the empirical importance of persuasion and slack; they are all around us. Now I will present a more speculative strategy for social change, inspired by my paper on "the idea trap" (Caplan 2003). This paper presents a simple politico-economic model with three variables: growth, policy, and ideas. Two of the relationships in this model are straightforward: good ideas cause good policy, and good policy causes good growth. The performance of the model hinges on a third relationship - the one between growth and policy.

Most economists - and probably laymen — assume what I call "negative feedback" from growth to policy. On this assumption, bad growth leads to good ideas, because undesirable outcomes inspire the public to search for wiser approaches. Good growth, in contrast, leads to bad ideas-perhaps because greater wealth makes the public more willing to sacrifice economic growth for other values.

As long as there is negative feedback from growth to ideas, my simple model has a unique steady-state equilibrium, in which growth, policy, and ideas all tend to be mediocre. If ideas are good, for example, this leads to good policies, which leads to good growth, which reduces the quality of ideas, which reduces the quality of policy, and in turn reduces growth. If ideas are bad, in contrast, this leads to bad policies, which leads to bad growth, which engenders a search for better ideas, which improves policy, and finally restores normal growth.

What happens, though, if there is positive feedback from growth to ideas - if good growth leads to good ideas, and bad growth to bad ideas? In my model, this alternative assumption implies multiple equilibria. There is still a steady-state equilibrium in which growth, policy, and ideas are all mediocre. But there is also a "good" equilibrium in which growth, policy, and ideas are all good, and a "bad" equilibrium, where growth, policy, and ideas are all bad. I call that last combination "the idea trap." In the idea trap, bad growth, bad policy, and bad ideas mutually reinforce each other. Bad ideas lead to bad policy, bad policy leads to bad growth, and bad growth in turn sows the seeds of bad ideas.

If one is willing to put stock in such a simple, reduced-form political-economic model, a great deal hinges on the real-world interaction between growth and ideas. If you believe in rational voter models, you will naturally expect the political system to constructively respond to bad performance, implying negative feedback. But besides the general evidence against rational voter models, there are at least two more specific reasons to favor the contrary assumption of positive feedback.

First, although good economic policies are virtually a sufficient condition for economic development, the convergence hypothesis fails. ${ }^{3}$ Poor countries could catch up to rich countries by mimicking their policies. But they typically fail to do so. These stylized facts are

\footnotetext{
${ }^{3}$ See Caplan (2003, p. 184) for detailed citations.
} 
easy to reconcile with positive feedback, because it implies the existence of multiple steadystate equilibria. Rich countries are usually safely nestled in a package of good growth, good policy, and good ideas. Poor countries, on the other hand, are stuck in the idea trap.

Second, there is also direct evidence of positive feedback from growth to ideas. Within the US, there is strong empirical evidence that people with rising income and high job security "think more like economists" than people with falling income and low job security (Caplan 2007, pp. 154-156). These effects are large. According to my estimates, the absolute value of the lay-expert belief gap for people with falling income and minimal job security is $85 \%$ larger than the gap for people with rising income and maximal job security. When a country's growth improves, then, we should expect public opinion to improve as well. ${ }^{4}$

If we suppose for the sake of argument that my model is correct, there are interesting implications about economists' ability to change the world. With negative feedback, economists can only temporarily improve economic performance. As explained, there is only one steady-state equilibrium in which growth, policy, and ideas are all mediocre.

With positive feedback, however, even one-time shocks from reformist economists can have a lasting impact. In fact, there are two channels through which economists can exert a durable influence. The first is economic education. Suppose economists raise the quality of public opinion by teaching, writing, and/or speaking. This improves the quality of policy, which raises growth, which in turn reinforces the quality of ideas. The second is policy-making. Suppose economists improve the quality of policy by taking advantage of their political slack. This raises growth, which improves the quality of ideas, which in turn engenders public support for better policies.

With a unique equilibrium, economists' eternal vigilance is the price of economic efficiency. With multiple equilibria, however, the price of economic efficiency may be much more affordable. One "big push" by reformist economists may be enough to permanently put their countries on the right track-or prevent their countries from falling into the wrong one.

In the original paper, I focus on two historical examples of "idea traps" (Caplan 2003, pp. 196-199). The first is the Great Depression. On my account, the Great Depression was triggered by negative growth shocks, which in turn degraded the quality of public opinion, leading to the adoption of bad policies, which further retarded growth. Economists probably could have averted this downward spiral by using their policy-making slack-especially over monetary policy—but they badly fumbled. My second example is Chile from the Allende years until the present. In this case, Allende's overthrow gave economists a chance to implement unpopular but growth-enhancing policies. By the time that Pinochet relinquished power, these policies had become democratically sustainable. Economists saw their chance to make a difference, took it, and put Chile on a steady course toward prosperity. The key feature in both cases is that economists' actions during critical episodes made a lasting economic and political difference.

The downside, as Spiderman knows, is that "With great power comes great responsibility." It is easy to "make a difference" in the wrong direction. I believe that this is precisely what leading policy economists have been doing during the past year: Instead of helping to calm foolish policy reactions, they have been actively making a bad situation worse. Ben Bernanke's remark that "There are no atheists in foxholes and no ideologues in financial crises," has been widely quoted. I would counter, though, that just as imminent personal

\footnotetext{
${ }^{4}$ Admittedly, this assumes that cross-sectional US evidence generalizes over time and across countries. This is part of the reason why I still consider this model relatively speculative.
} 
danger is a bad argument for the existence of God, financial crisis is a bad argument against orthodox economic policies. Economists who want to improve the world, not just change it, should not just sit around waiting for the next critical period. They should be honing their skills and stockpiling solutions to the hard problems instead of echoing the now-popular syllogism that, "Something must be done; this is something; therefore this must be done."

\section{Conclusion}

Economists need to learn from Rudyard Kipling's admonition to "keep your head when all about you/Are losing theirs and blaming it on you." Econ 101 is rarely popular. The public's beliefs about economics - and probably many other subjects - are often distressingly irrational. But this is no reason for economists to despair. Fatalism is false; though the world often ignores us, we still have plenty of chances to nudge it in a better direction. Economists raise the quality of economic policy every day-directly as policy-makers, indirectly as educators and public intellectuals. Many countries are prosperous today because their economists put their policies on the right track decades or centuries ago.

At the same time, economists can do better. Most of us remain mediocre communicators. By following a few simple guidelines, we can become far more informative and convincing. Most of us also remain ambivalent about using slack to push the world in a better direction. Once we take a realistic look at public opinion, though, the normative case for secondguessing "the will of the people" grows very strong. When a principal fails to understand his own interests, an agent who objects or disobeys does him a favor.

In my view, everything this paper says follows readily from the main theses of $M R V$. Unlike most of the rational choice competition, moreover, $M R V$ does not dogmatically dismiss proposals for reform with the blanket objection that, "If it were a good idea, it would already have happened." Why, then, do so many readers interpret my book as a defense of fatalism? The main reason, as best as I can tell, is that my book implies that sharp improvements over the status quo are unlikely to happen. In response, though, I have to ask, "Doesn't any sensible theory of political economy have the same implication?" Sharp policy changes have always been rare. That's life. Economists who want to make the world a better place have to understand their constraints before they can figure out the best way to overcome them.

\section{References}

Becker, G. (1968). Crime and punishment: an economic approach. Journal of Political Economy, 76(2), 169217.

Caplan, B. (2003). The idea trap: the political economy of growth divergence. European Journal of Political Economy, 19(2), 183-203.

Caplan, B. (2007). The myth of the rational voter: why democracies choose bad policies. Princeton: Princeton University Press.

Caplan, B. (2009). Irrational principals. Review of Austrian Economics, 22(2), 159-167.

Levy, D. (2008). Public choice for sheeple: a review of The Myth of the Rational Voter: why democracies choose bad policies. Journal of Economic Behavior and Organization, 69(3), 288-294.

Wittman, D. (1995). The myth of democratic failure. Chicago: University of Chicago Press. 